\title{
Wyszukana prawda Józef Pankiewicz o sztuce w kontekście malarskiego warsztatu
}

\author{
Całe jego àcie jest poszukiwaniem własnej prawdy w sztuce \\ i najkulturalniejszego wyrazu ${ }^{1}$.
}

Spojrzenie na dzieło Józefa Pankiewicza jako na istotne ogniwo łączące Polską sztukę z żywym krwiobiegiem sztuki zachodniej ma swoja ugruntowaną tradycję. Twierdzenie, że jego twórczość „pomostem łączy nas ze sztuką Europy"2, czy określenie przez Pierre'a Bonnarda talentu malarza jako „znamionującego człowieka łacińskiej kultury” oraz uznanie go jednocześnie „za jednego z naszych” 3 - sugeruje odbiór postawy twórczej Pankiewicza jako spójnej z prądami artystycznymi ówczesnego Paryża. W pierwszych latach XX wieku współtworzył on jego środowisko, a w bogaty artystyczny krajobraz miasta wprowadził wielu młodych zdolnych adeptów krakowskiej uczelni, silnie wpływając na ich dalsze wybory artystyczne, jak i zbudowanie języka, bez którego niemożliwe byłoby

1 S. Szczepański, Sztuka Pankiewicza, „Wiadomości Literackie”, 1933, nr 24.

J. Wolff, Pankiewiczi i Boznańska, „Głos Plastyków”, grudzień 1946, s. 12.

3 Idem, Listy P. Bonnarda do J. Pankiewicza, „Głos Plastyków”, wrzesień 1948, s. $70-71$. 
tak pełne i dojrzałe ukształtowanie się całego nurtu koloryzmu w formie, w jakiej go obecnie znamy.

Artystyczne pytania epoki ogniskują się jako aktualne i żywe problemy w całym dziele Pankiewicza. Obok zachłannej „absorpcji” mamy jednak krytyczną selektywność, a baczna obserwacja twórczości innych i bliska z nimi współpraca nie są powodem powierzchownych zapożyczeń, lecz raczej twórczym, często krytycznym dialogiem ${ }^{4}$. Warto więc przyjrzeć się celom i środkom towarzyszącym według Pankiewicza tworzeniu, opierając się na wypowiedziach artysty oraz jemu współczesnych.

Podstawowe źródło niniejszych rozważań stanowią wykłady wygłoszone dla krakowskich studentów. Prowadzone w Luwrze w gronie przyszłych kapistów, zostały zredagowane przez Józefa Czapskiego ${ }^{5}$. Teksty te uzupełniaja wspomnienia pasierbicy malarza - Jadwigi Dmochowskiej ${ }^{6}$.

„Zanim zdamy sobie sprawę z tego, co obraz przedstawia, uderza nas on jako ozdobiona w pewien sposób powierzchnia [...], strona materialna powierzchni jest podstawą naszego estetycznego wrażenia"”. Przy okazji wizyty Józefa Czapskiego w pracowni profesora usłyszał on to swoiste credo artysty. „Strona materialna powierzchni”, jej konkretny wygląd jeszcze nie plamy barwne i ich relacje, lecz powierzchnia odczuwana jako substancjalna całość w swej konkretności, lśnieniu, kosztownej materialności, ma według Pankiewicza służyć zadowoleniu i estetycznej, sensualnej przyjemności. Komentując Madonne Kanclerza Rolin Jana van Eycka, dopowiada: „Słusznie porównano przedziwnie drogocenną materię tego obrazu do wypolerowanej powierzchni agatu"».

4 O wpływach na twórczość Pankiewicza, ich różnorodności i złożoności zob. J. Janowski, Józef Pankiewicz. wobec „łacinskiej tradycji” malarstwa europejskiego, „Pamiętnik Sztuk Pięknych", 2003, nr 4; o autonomicznej, krytycznej, selektywnej postawie wobec bieżących prądów artystycznych zob. M. Wachowiak, Józefa Pankiewicza twórçy dyskurs z. awangarda, [w:] Wiek awangardy, pod red. L. Bieszczad, Kraków 2006, s. 423-442 .

J. Czapski, Życie i dzieło. Wypowiedzi o sztuce, Warszawa 1936.

J. Dmochowska, W kregu Pankienicza. Wspomnienia i listy 1906-1940, Kraków

1963.

J. Czapski, Życie, s. 183.

8 Ibidem, s. 145. 
Sposób „myślenia malarskiego”, wartościowanie estetycznych składników dzieła opiera jednak Pankiewicz na monolicie Paula Cézanne’a, o którym mówi:

żaden z artystów współczesnych nie zdawał sobie tak jasno sprawy z zadań malarstwa, jak Cézanne. Wszystkie formy redukują się do brył geometrycznych, wszystkie kolory i tony są kontrastami, które stanowią o wartości plastycznej płaszczyzny obrazu [...] tą drogą otrzymuje Cézanne harmonię, którą Grecy określali jako „zjednoczenie różności i uzgodnienie niezgodności”’"

Jak zauważa Czapski ,jedna z zasadniczych rewolucji Cézanne’a, [...] [jest] całkiem świadome scalenie rysunku i koloru w obrazie, przy tym uznanie koloru, a nie rysunku za konstrukcyjny punkt wyjścia płótna i wartość nadrzędną"10.

Stąd Pankiewicz, jako jeden z apologetów Cézanne’a, nie ignoruje muzyczności przedstawienia wynikającej z kolorystycznych zestawień. Przeciwnie - jak wspomina: ,już w pierwszych przeżyciach malarskich czułem logikę kontrastów i jeżeli zapaliłem się do Gierymskiego, to dlatego właśnie, że na jego płótnach widziałem działanie prawa kontrastów"11. Mówi o „muzykalności i szlachetności barwy” Canalletta ${ }^{12}$, o obrazach Veronesego, że „daja zadowolenie równie niematerialne jak muzyka”, a o Tycjanie, iż umiał „zorkiestrować (a po nim Rembrandt) najbogatsze

9 Ibidem, s. 136.

10 J. Czapski, Patrzac, Kraków 1983, s. 54; w książce Balzaca Le chemvres d'ouvre Inconu z 1832 r., którą obaj malarze cenili, czytamy: „Ściśle mówiąc, rysunek nie istnieje! [...] nie ma linii w naturze [...] wmodelowując dopiero rysujemy, tzn. wydobywamy rzeczy z otoczenia, w którym się znajduja”, ibidem, s. 55; podobnie brzmią słowa Cézanne’a: „Rysunek i kolor nie są czymś różnym. Malując, rysujemy. Im bardziej kolor się harmonizuje, tym rysunek jest bardziej precyzyjny. Kiedy kolor jest u szczytu bogactwa, wtedy forma osiaga pełnię", ibidem, s. 61.

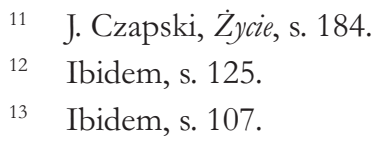


gamy kolorów i tonów"14. Podkreśla ich umiejętne zestawienia kolorów dopełniających oraz tonów ciepłych i zimnych.

Artysta propagował dźwięcznie zharmonizowany kolor, który jednocześnie oddaje formę przestrzenną oraz materię przedmiotu. Dlatego też akcentuje walor, krytykując impresjonistów za „zgubienie przedmiotu”, a Bonnarda - za „porzucenie poczucia materialności” ${ }^{16}$. Walor jest istotny nie tylko ze względu na powiązanie z kolorem, którego intensywność i jakość modyfikuje ${ }^{17}$. Umożliwia on również budowanie przestrzeni za pomocą światłocienia. Ta jest ważna, gdyź świat widzialny jest dla artysty punktem wyjścia i odniesienia, a „w naturze mamy tylko przedmioty ustawione w różnych planach" ${ }^{18}$. Ponadto konsekwentnie budowana przestrzeń umożliwia kompozycyjne scalenie obrazu i nadanie mu logiki przez użycie światłocienia.

Z wiernością naturze, przedmiotowościa, obok przestrzenności, wiązał Pankiewicz również oddanie materii: „materiał przedmiotów jest scharakteryzowany swą właściwościa pochłaniania lub odbijania światła"19. Kolor jest istotny z jednej strony jako część muzycznej całości, powiązanej ze sobą wzajemnymi stosunkami przez harmonię i kontrasty, a jednocześnie, jak w obrazie Colosseum (1826) Camille’a Corota, przez akcentowanie „wartości syntetycznej plamy kolorowej, wyrażającej jednocześnie światło i materiał przedmiotu" ${ }^{20}$. Analizując niesamowita grę światłocienia u Adriaena van Ostade, Pankiewicz stwierdza, że podobnie

\footnotetext{
Ibidem, s. 137.

Ibidem, s. 139.

Ibidem, s. 165.

7 „[... zmiana intensywności waloru powoduje zmianę koloru, nie tylko zmianę jego natężenia. Można to porównać z komentarzami Bergsona o związku między jakością i ilością (qualite i quantite). Bergson ilustruje to przykładami z dziedziny fizjologii. Kiedy nas bolą zęby i ból się zmniejsza, zmniejsza się nie tylko »ilość«, ale i »jakość« - ból staje się inny”, ibidem, s. 162.

18 Ibidem, s. 113.

19 Ibidem, s. 108.

20 Ibidem, s. 133.
} 
jak Rembrandt, z samego światła uczynił on oś dzieła, nie niwecząc jednak przedmiotu, co jest jedną $z$ wad impresjonizmu ${ }^{21}$.

Znacznie większą wagę niż współcześni przywiązywał Pankiewicz do rysunku i poprawności anatomii. Wydaje się, że rysunek jest dla niego wyrazem uczciwości malarskiej ${ }^{22}$, warsztatowej solidności i wierności naturze. Jak szczegółowo analizuje pod tym kątem dzieła, pokazuje wychwycenie źle narysowanej dłoni w Portrecie pani Cordier Jeana A. D. Ingres'a ${ }^{23}$, a poprawnie np. w Autoportrecie z ostem Albrechta Dürera ${ }^{24}$.

Akcentowanie tradycyjnych wartości plastycznych - poprawnego rysunku z poszanowaniem proporcji, przestrzenności budowanej światłocieniem i walorem - nie jest przypadkowe. Umożliwiają one realizację jednego z podstawowych według niego, obok funkcji czysto dekoracyjnej, zadań malarstwa, tj. oddawania natury - przedmiotów i ludzi, w ich wewnętrznej „prawdzie” i „tajemnicy” z maksymalnym obiektywizmem wypływającym z uczciwego, wzrokowego studiowania. Znamienne sa niejednokrotnie przywołane przez artystę postulaty: „prawdy” w stosunku do natury oraz uchwycenia ,życia" ${ }^{25} \mathrm{w}$ przedstawieniach człowieka. W ostatnim chodzi o możliwie głęboki ogląd humanistycznej pełni osoby. Ulotne pojęcia prawdy w obrazie oraz życia postaci są realizowane w sposób bardzo konkretny, z użyciem analizowanych wcześniej plastycznych środków: „,nie ma nic bardziej prawdziwego od siły wyrazu każdej postaci aż do układu draperii. To jest prawda, o którą w obrazie artyście chodzić powinno" ${ }^{26}$. Obiektywizm ma więc swe źródło w wierności zobaczonemu. By wyjaśnić rolę pierwiastka bardziej ogólnego, humanistycznego, Pankiewicz odwołuje się do mistrzów dawnych: „W dziełach wielkich mistrzów powierzchnia obrazu nie jest w sprzeczności z tym, co wyobraża,

21 „Oni [impresjoniści] jednocześnie zgubili przedmiot i nie osiagnęli wskutek tego poezji światła oświetlającego”, ibidem, s. 148-149.

22 Słowa: „Rysunek jest uczciwością malarstwa” przypisuje się Ingres’owi.

23 Ibidem, s. 115.

24 Ibidem, s. 144-145.

25 „Lubi wówczas powtarzać, że rację miał Vasari, gdy jako najwyższą pochwałę o obrazie mówił come vivo", J. Czapski, Raj utracony, [w:] idem, Patrąc, Kraków 1983, s. 126.

26 Idem, Życie, s. 108. 
a wartość malarska odpowiada zawsze wartości ludzkiej. [...] Wizja natury jest źródłem niewyczerpanym form i barw dla oka malarza"27. By pełniej jeszcze zilustrować swe poglądy, cytuje traktat Dürera: „Prawdziwa sztuka tkwi w naturze, kto ją może z niej wydobyć, ten ja posiada. Im bardziej dzieło twoje zgodne jest z życiem, tym jest lepsze"28. Pankiewiczowi nie chodzi jednak o dosłowny realizm. Wszak stwierdza - opowiadając o obrazie Fra Agelica, bynajmniej nie czysto realistycznym - że pejzaż jego „oddycha prawda”, ale „nie jest on tylko dekoracja”, ponieważ „niebo, ziemia, drzewa są widziane i odczute" ${ }^{\prime 2}$. Istotę stanowi więc nie tylko element obiektywnego patrzenia, ale i emocji, wzruszenia, a miejscami i delikatnej stylizacji, jak w przypadku Alesso Baldovinettiego, u którego linia jest „pełna prawdy, a jakże przy tym wyszukana”30. Kluczowym elementem wydaje się zatem pierwotna postawa afirmacji rzeczywistości jako źródła tworzenia. Znamienne, że w całej twórczości artysty - która, jeśli jest „prawdą" wierna naturze, to jednak „wyszukana” - mimo świadomej dekoracyjności, a w okresie hiszpańskim, także syntetyzowania bryły, nie znajdziemy w jego obrazach elementu deformacji, a przynajmniej nie w takim jej rozumieniu, jak np. u Chaima Soutine’a czy twórców ekspresjonizmu niemieckiego.

Pankiewicz potępiał zarówno „estetyzowanie uczuć”31, jak i „skrajny subiektywizm”, kładąc nacisk na to, że „widzenie zależne jest nie tylko od naszego temperamentu, ale i od naszej woli widzenia tak czy inaczej”32. Jednocześnie sprzeciwiał się zbytniemu intelektualizmowi w sztuce, który niósł ze sobą klasycyzm ${ }^{33}$ czy „pseudonakowy” neoimpresjonizm ${ }^{34}$.

27 Ibidem, s. 137-138.

28 Ibidem, s. 178.

29 Ibidem, s. 181.

30 Ibidem, s. 111.

31 Ibidem, s. 145.

32 Ibidem, s. 171.

33 Między innymi o Praysiędze Horacjuszy Davida mówi: „Nie można na te obrazy reagować uczuciowo, trzeba je przyjąć rozumem. Dlatego odtąd zaczyna być źle z malarstwem", ibidem, s. 131-132.

34 Ibidem, s. 135 
Artysta pochwala ekspresję, jednak tę związaną z „napięciem uczuciowym" przedstawionych postaci, mniej - malującego je twórcy.

Pankiewicz po raz kolejny skłania się ku mistrzom dawnym, rozważając problem kompozycji. Jej podstawą ma być jedność przedstawienia, umiar i porządek, osiagane przez logikę światłocienia, rytm, równoważenie się kolorystyczne i walorowe plam. Brzmiąca po trosze jak manifest artystyczny malarza wypowiedź: „,na tym polega dzieło sztuki, że człowiek grupuje elementy świata i wprowadza w świat zewnętrzny ład i liczbę. Najbardziej obcym żywiołem sztuki jest bezład”, ilustrował przykładem Nicolasa Poussina ${ }^{35}$. Istotna, oprócz porządku kompozycyjnego, jest też współzależność, ścisłe powiązanie elementów, z których żaden nie może działać jako wyizolowany czynnik. Niezmiernie dla Pankiewicza ważna wartość muzyczna przedstawienia osiaga się przez „orkiestrację” wszystkich różnorodnych środków, które jednak nie burzą jednolitości dzieła, ale przez wzajemne ustosunkowanie i współgranie jeszcze ja podkreślaja. Analizując Tycjana, akcentuje: „jednakowość napięcia barwy na calutkiej powierzchni obrazu"36 oraz rolę spajająca światła ${ }^{37}$. Wszystkie rozpatrywane dotychczas środki plastyczne jako osobne i autonomiczne - w kompozycji znajdują wspólny mianownik, warunkujący i ilustrujący jedność uporządkowanego formalnie dzieła.

Tak jak oddanie prawdy natury wymaga konkretnych środków plastycznych, tak efekt wizualny osiaga się dzięki świadomemu użyciu narzędzi i znajomości zasad malarskiego rzemiosła. U Dürera podkreśla Pankiewicz „inteligencję wizji”, zachwyca się kompozycją Nicolasa Poussina „skonstruowaną całkiem świadomie" "38 a w Canalletcie rozkoszuje się „wysokim gatunkiem gry barwnej [...], obiektywnie ścisłej”39. Spoglądając wstecz, wskazuje na „związek między umiejętnością artysty a wizją"40. Rozpacza nad upadkiem rzemiosła, boleje nad ignorancją wielu współczes-

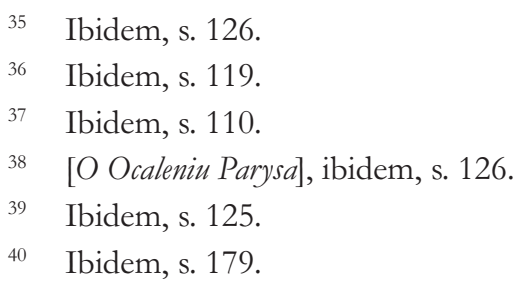


nych w podstawowej malarskiej wiedzy ${ }^{41}$. Według niego dawni mistrzowie doskonale rozwiązali intuicyjnie formalne zadania, z którymi nie radza sobie XIX-wieczni twórcy ${ }^{42}$. Przypominając, ile studiowaniu i kopiowaniu dzieł dawnych zawdzięczają Gustave Courbet, Édouard Manet, Paul Cézanne, twierdzi, że „od odzyskania tej wiedzy rzemiosła zależy przyszłość malarstwa" ${ }^{\sharp 3}$. Sam studiuje mistrzów w oryginale w trakcie licznych podróży do Włoch, Hiszpanii, Belgii, Holandii, Austrii. Wykonuje też kopie z Rubensa, Veronesego, Tycjana. Kontakt z dziełami dawnymi od czasu pierwszego młodzieńczego pobytu w Petersburgu kształtował malarza nie mniej niż twórczość współczesnych, z której też jednak obficie czerpał. To z wizyt w licznych muzeach wyniósł artysta kult malarskiej solidności i świadomość roli użytych środków i materiałów.

Uczeń Jan Cybis tak pisze o swoim profesorze: „Sztuka i jakość były synonimem dla Pankiewicza. Ten postulat jakości rozciagał aż na materiał, którym pracował, aż na narzędzia, którymi się posługiwał. Popatrzmy na papiery, na których rysował... Jego dobre obyczaje rzemieślnicze przywodzą nam na myśl raczej takich par excellence sztalugowców i praktyków jak dawni Holendrzy"44.

Podobne opinie, świadczące o przywiązywaniu wagi do użytych materiałów oraz perfekcji warsztatu twórczego, znajdujemy również we wspomnieniach pasierbicy malarza: „dobierał najpiękniejsze papiery czerpane, chińskie, japońskie [...] pamiętam nawet odbitkę zrobioną na pergami-

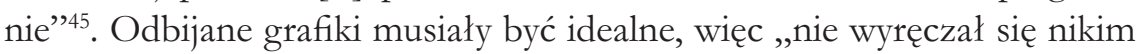
- trawił i odbijał zawsze sam [...]"46, a względem odbitych kilkakrotnie płyt graficznych (akwafort i suchej igły) daje wskazówki Dmochowskiej: „przetopić na patelnie, byle dalej nie reprodukować” ${ }^{47}$. Wspomina ona, że

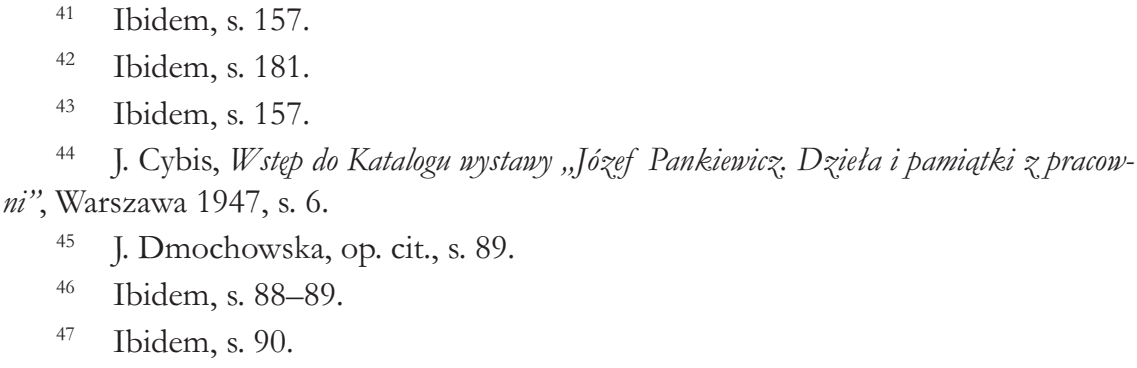


„malował zawsze cały ranek”48. Zdanie to sugeruje ciagłość i systematyczność pracy twórczej $j^{49}$.

Malując, artysta wykorzystywał lustro, sprawdzając „to, co widziały jego oczy, i to, co ręka przenosiła na płótno" ${ }^{50}$. Otwarta pozostaje kwestia korzystania z fotografii. Dmochowska sugeruje, iż artysta nie uciekał się do jej pomocy ${ }^{51}$. Zachowane fotografie $z$ czasu prac nad Japonka pokazuja co prawda, że Pankiewicz zrezygnował z lustra w tle, pozę modelki zmodyfikował jednak tylko nieznacznie. Zdjęcie natomiast pozującego do portretu przy fortepianie Feliksa Jasieńskiego jest raczej dokumentacja pracy niż pomoca przy malowaniu ${ }^{52}$. Opierał się w pracy „na notatkach bądź rysunkowych, bądź pisanych"53. Oprócz licznych szkiców rysunkowych do obrazów oraz akwarelowych bądź olejnych projektów i wariantów ostatecznych przedstawień, zachował się szkic z notatką definiującą kolor pejzażu z myślą o mającym powstać obrazie ${ }^{54}$.

Cenne informacje o warsztacie artysty w latach 20. przytacza Czapski:

48 Ibidem, s. 148.

49 „Stary Pankiewicz mawiał, że nie warto malować, jeżeli się nie ma przynajmniej 50 lat czasu na naukę", J. Czapski, Tadeusz Piotr Potworowski, [w:] idem, Patrzac, s. 292.

50 Dmochowska dodaje, że „był to okres, gdy lubował się w odbiciach w lustrze", wspominając prace nad Japonka, a także projekt portretu [Pankiewiczowej] z „odbiciem twarzy w lustrze o szerokich, antycznych ramach”, J. Dmochowska, op. cit., s. 65, być może jego realizacją jest Kobieta cz̧eszqca się, 1911, własność Muzeum Narodowego w Krakowie.

51 Ibidem, s. 65.

52 Fotografie pozującej do obrazu Japonka Wandy Pankiewiczowej reprodukuje J. Dmochowska, op. cit., s. 62, fotografie pozującego Feliksa Jasieńskiego, repr.: ibidem, s. 61.

53 Ibidem, s. 65.

54 „U samej góry nad dużą sosną, białe mocno skontrastowane obłoki, drobne, poszarpane na tle nieba ciepłofioletowego. Pień oliwki pochylonej obok dużej na lewo, zimny jak pień duży i ten na prawo, na brzegu obrazu. Oliwka na tle morza mocniej skontrastowana. Głównie pień i gałęzie na ziemi pod tą oliwką sjena, źółtawe jaśniejsze smugi. Na morzu, drobne smugi fiol. ukośne, zmniejszające się w oddali. Sosna duża więcej przezroczysta”, ibidem, s. 104. 
[Pankiewicz] wraca do klasycznej metody pracy (rysunek - walor kolor) [...] podrysowuje obraz przed malowaniem, [...] używa podkładów [...]. Przed ostatecznym położeniem koloru zielonego lub czarnego kładzie Pankiewicz plamy gorące i wzbogaca tym dźwięczność tonu (zwęża paletę [...] poza koniecznością oddania koloru lokalnego, maluje prawie wyłącznie kilku ziemiami i czernią. Nawet w domieszkach używa niechętnie niebieskich kolorów i woli posługiwać się czerniąa ${ }^{55}$.

Czapski podaje również pełną paletę malarza w tym okresie, potwierdzającą celowe, znaczne jej ograniczenie ${ }^{56}$.

Pankiewicza technologa poznajemy, obserwując razem z nim obrazy prezentowane we francuskich zbiorach. Analizie formy często towarzyszą spostrzeżenia warsztatowe. Według Pankiewicza „Starzy mistrzowie znali technikę podkładu"57, ale przy obrazie Ribery Kuternoga sugeruje, że był malowany alla prima ${ }^{58}$. Oglądając Domenica Veneziana, wskazuje na podmalowanie karnacji Dzieciątka ziemia zieloną ${ }^{59}$. U Bassana analizuje laserunki z „laki purpurowej, szkarłatnej, żółtej lub zielonej”, kładzione na jasne impasty ${ }^{60}$, a u Gerarda Davida i van Eycka zwraca uwagę na wysokie impasty ciemnych fragmentów ${ }^{61}$. Charakteryzując technikę malarską tych ostatnich, stwierdza: „Sa to farby olejne, ale oczywiście całkiem inne

55 J. Czapski, Życie, s. 94-95.

56 „Paleta dzisiejsza Pankiewicza: biel srebrna, żółta neapolitańska, żółta brylantowa, ochra żółta, umbra, czerwień indyjska, sienna, palona, umbra, naturalna czerń z kości słoniowej. W pejzażach posługuje się jeszcze dodatkowo chromem jasnym, jaune de Strontaine, kobaltem, ultramaryna, zielenią kobaltowa. Nie używa nigdy zieleni szmaragdowej ani kadmiumów, lazur krapowy, cynober, błękit pruski stosuje w wyjątkowych tylko wypadkach", ibidem, przypis 1, s. 94.

57 Ibidem, s. 146.

58 Ibidem, s. 123.

59 Tzw. verdacio, o którym w swym traktacie wspominał Cennini, a Pankiewicz zauważał: „Jest to proceder uprawiany przez ówczesnych malarzy”, ibidem, s. 171. Znajomość tego szczegółu może świadczyć o czytaniu przez Pankiewicza traktatu Cenniniego (w pewnym okresie swej twórczości studiował go Renoir).

60 Ibidem, s. 161.

${ }^{61}$ Ibidem, s. 146. 
od naszych" ${ }^{\prime 2}$. Sąd ten powtarza również przy obrazie Jeana Moulliona: „I jakie farby mieli ci ludzie! Kwiaty czerwone w niebieskim wazoniku do dziś dnia zachowały swą intensywność, która w płótnach, malowanych dzisiejszymi farbami, po kilkunastu latach zaczyna już gasnaćc" ${ }^{63}$. Wiedza i świadomość ujawniają się także, gdy artysta wspomina o możliwości ciemnienia niektórych pigmentów ${ }^{64}$, o wpływie na odbiór dzieła żółknącego werniksu ${ }^{65}$ oraz przeprowadzonych na obrazie konserwacji i restauracji ${ }^{66}$. Jego spostrzeżenia świadczą o postawie analizującego technologa, skupiającego się na użytych materiałach i technice, służących osiagnięciu oczekiwanych efektów plastycznych.

Poświęcenie artysty, chcącego uzyskać najdoskonalszy efekt w obrazie, uwidacznia jego odpowiedź na pytanie pasierbicy o powód zaniechania polskiego pejzażu: „Cały charakter polskiego krajobrazu leży na linii horyzontu. Żeby to oddać, trzeba położyć się na ziemi, godzinami leżeć w bruździe. Robiłem to kiedyś, teraz przekracza to moje możliwości’" ${ }^{\prime \prime}$.

Przemówienie z 1928 roku podsumowuje malarskie przemyślenia Pankiewicza: „Po długim dopiero szukaniu i błądzeniu, [...] odkrywa się i autentyfikuje naturę: prawda istnieje tylko w sztuce! [...] Obowiązkiem [...] każdego artysty jest przede wszystkim dążenie do poznania środków potrzebnych do zrealizowania w danej materii formy, która stwierdza zrozumienie" $"$.

W tej przemowie zawiera się akcentowanie rzemiosła i warsztatu oraz ogromna skromność i pokora artysty. Nie powstrzymują one jednak profesora przed ostra, dogłębną krytyką współczesności: „Brak wiary stworzył dziką mieszaninę pojęć, chaos, wypaczenie ludzkiego oblicza. [...] wszyscy się spiesza, [...] nikt nie chce i nie może zdobyć się na prawdziwą ciagłość skupienia [...]. Mamy dziś z jednej strony rozbicie psychiczne

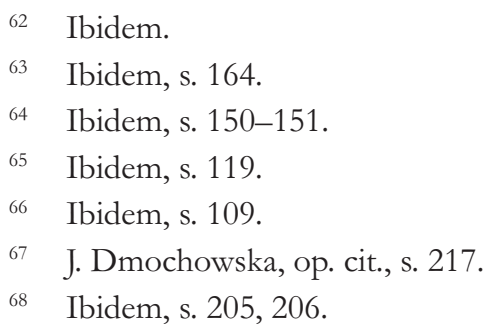


i moralne człowieka, z drugiej obniżenie rzemiosła"69. Na krytyce jednak nie poprzestaje. Receptę ma stanowić $z$ jednej strony studiowanie natury, z drugiej - sposobu jej przedstawienia przez dawnych mistrzów, po to, by u nich odnaleźć właściwe środki plastyczne i metody malarskie, by nie „dreptać wokół rozwiązanych” już „problematów” ”0 by wrócić do „wiecznej zasady malarstwa - plastyczności”, i z dzieł dawnych uczyć się zapomnianego warsztatu ${ }^{71}$.

Trudno byłoby dziś wzywać współczesnych do dosłownego studiowania natury, czego zreszta i sam Pankiewicz nie czynił. Zapytany o deformacje w obrazie Cézanne'a Grajacy w karty (1890-1892), odpowiada: „nie widzę tu nic poza wyczuciem charakteru tych postaci, poza ostrościa widzenia”. Przy bliższym oglądzie okaże się, że spojrzenie artysty na naturę jest osobiste - jednak nie w sensie silnej, ekspresyjnej deformacji, ale rozumiane jako selektywność, unikanie tego, co niepokojące, a jednocześnie intensyfikowanie warstwy dekoracyjnej dzieła. „Ostrość widzenia” - którą chętnie przypisalibyśmy ekspresjonistom - nie będzie zatem spojrzeniem wyzywającym, ale kontemplacyjnym. Wojnę i cierpienie w swojej wizji natury artysta skrzętnie pominął. „Ostre”, a raczej uważne spojrzenie objawił głównie wobec „przedmiotu”, z jego dotykalną materialnościa $\mathrm{i}$ jasnym posadowieniem w przestrzeni.

Kluczowe dla zrozumienia zasygnalizowanej selektywności widzenia wydaje się pojmowanie przez Pankiewicza malarstwa jako rozkoszy, przyjemności. Wyznanie: „Urok zmysłowy jest przynętą nieodzowną dla przeczucia tajemnicy życia. Sztuka musi być rozkoszą, dzięki której objawiaja się nam prawdy inną drogą niedostępne" 72 - nosi znamiona osobistego manifestu. Wpatrywanie się w obraz Rembrandta Betszabe - jak sam wspomina - spowodowało śmiech, współuczestniczenie w ponadracjonalnej malarskiej uczcie, sensualnej przyjemności, kojącej i rozkosznej ${ }^{73}$.

Droga twórcza Pankiewicza to szukanie złotego środka - malarstwo pogodzonych sprzeczności. Definiuja je pary antynomii: sztuka i natura,

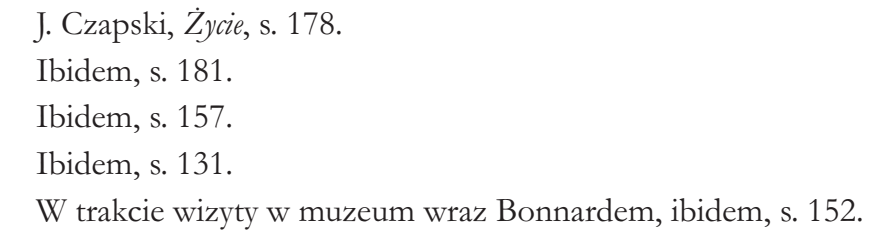


obiektywizm i subiektywizm widzenia, prawda, ale wyszukana, rysunek, lecz tylko jeśli jednocześnie malarski, dekoracyjne rozumienie powierzchni obrazu, z zachowaniem jego głębi przestrzennej, świadomość i wzruszenie, zdyscyplinowana konstrukcja i jednocześnie kolorystyczna muzyczność. Jego twórczość to wola kształtowania i rozkosz poddawania się, tradycja, ale zobaczona przez środki malarskie wydzielone tak mocno od siebie nawzajem dopiero przez awangardowy wiek XX. Malarstwo krakowskiego profesora to świeże spojrzenie bez przekreślania natury, oddawanie malarskiego wzruszenia bez popadania w egzaltację. Wszystkim rządzi umiar. Stąd wbrew awangardzie bronił rysunku, waloru, przedmiotu, przestrzeni, jedności kompozycyjnej. Przed sztywnością, oschłościa spojrzenia ustrzegło go umiłowanie kolorystycznej gry, aż po muzyczność, dźwięczność barwy. Przed pełnym poddaniem się autonomicznym środkom malarskim wstrzymywało go studiowanie i kontemplacja natury. Wprowadzając w orbitę oddziaływań awangardowej sztuki polskiej postaci takie jak Mojżesz Kisling, sam pozostał wierny z pokora wyznaczonemu celowi - obrazowi sprawiającemu i wyrażającemu radość z ujrzanego fragmentu natury. Taka postawa w epoce mnożących się propozycji antynaturalistycznych musiała napawać pod koniec życia gorycza, osładzaną niejednokrotnie spojrzeniem w przeszłość, na przekór hałaśliwym awangardom. Wzajemne przenikanie starego i nowego, najbardziej według krakowskiego profesora zapładniające, definiuje w rozmowie z jednym ze swoich uczniów, Janem Jaremą: ,Ja nie mówię, żeby imitować Renesans albo Holendrów - to by było zupełnym niezrozumieniem - ja uważam stanowczo, że trzeba iść do sztuki Włochów i Holendrów przez Paryż, przez współczesny stosunek do nich"'74.

Co dało twórczej drodze Pankiewicza, mimo zaakcentowanych sprzeczności, antynomii, w dziele jednak najczęściej z sukcesem pogodzonych, taką spójność i jakość? Można zaryzykować stwierdzenie, że przed bezpłodnym falowaniem wraz z każdą nowinką i -ižmem’ chroniła go, przy poszanowaniu prawideł gier barwnych, wielka radość malowania tego, co widzi - afirmacja rzeczywistości, wsparta solidnym warsztatem i ciagle na s. 8 .

74 J. Jarema, Rozmowa z Jórefem Pankiewiczem, „Głos Plastyków”, 1933, nr 1-2, 
nowo odrabianą lekcją z mistrzów, zarówno tych „Starych”, jak i nowych klasyków współczesności formatu Cézanne’a.

\section{Summary}

\section{The refined truth. Józef Pankiewicz on art in the context of the workshop practice}

Pankiewicz as conscious artist of his time was absorbing achievements of innovative movements appearing throughout his life. Yet he was critical and did choose sources of inspirations selectively. Some traditional elements of the work of art as proportion expressed with proper drawing, or homogenous, balanced and united composition as well as space gained with the light and shadow did still matter for him. On the other hand he admired colourful interaction, simultaneous contrast and musical harmonies of the perfectly juxtaposed hues. His art can be characterised by pairs of oppositions like truth, but refined, nature observed but in the same time felt with emotion, the joy of painting but controlled with conscious will, proceeding rationally to the final effect. He treated very seriously also the technical part of work using high quality materials and studying Old Masters to learn methods of solution of formal and technological problems. Lack of technological knowledge and practical workshop practice seems for Pankiewicz to be the source of many problems of the "young art." Yet tradition did not close him on new propositions of avant-garde and especially of colouristic achievements. Defining in the modern way work of art at first as decorative surface giving joy to the eyes he did not resigned from nature as source of main inspiration. His art continuously evolving kept its solidness by creative dialogue of old and new confronted with strict clear sight directed to visible reality and softened by delight with colour. Inspired with Cézanne and his words on the unity of the drawing and colour, he was going his own path faithful to nature seen with the fresh eye of the joyful but conscious colourist. 